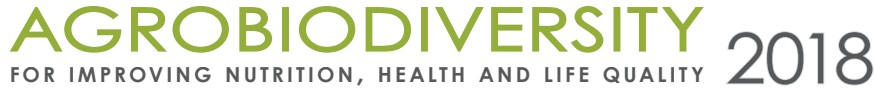

e

\section{COMPARATIVE STUDY OF MORPHOMETRIC CHARACTERISTICS AND MINERAL COMPOSITION OF POLLEN MALUS DOMESTICA BORKH.}

\author{
Motyleva Svetlana $^{1 *}$, Šimková Jana ${ }^{2}$, \\ Horčinová Sedláčková Vladimíra ${ }^{2}$, Brindza Ján ${ }^{2}$
}

\begin{abstract}
${ }^{1}$ Federal State Budgetary Scientific Institution "All-Russian Horticultural Institute for Breeding, Agrotechnology and Nursery"Moscow, Russia

${ }^{2}$ Institute of Biodiversity Conservation and Biosafety, Slovak University of Agriculture in Nitra, Slovak Republic
\end{abstract}

Received: 30.11.2018 Revised: 15. 11.2018 Published: 18. 12. 2018

\begin{abstract}
Pollen apitherapy has value, because its composition is a mixture of valuable nutrients. Among them there are mineral substances that are the purpose of this study. In this work, macro (K, P, Mg and Ca) and oligo-mineral elements (Mo, S and Zn) were studied by energy dispersive spectrometry in ash Malus domestica Borkh. pollen samples from different ecological and geographical areas - Slovakia (Nitra) and Russia (Moscow). The mass fraction of elements in ashed pollen samples. The main elements in the composition of pollen are potassium (19.96-24.29) and phosphorus (5.54-6.81). Molybdenum and calcium are contained in approximately equal amounts (3.79-4.95) mass\% in ash. The proportion of sulfur does not exceed 1.98, zinc $0.57 \%$ mass. In pollen samples from Slovakia, the proportion of potassium and phosphorus is higher by $18 \%$. In pollen samples from Russia, the proportion of magnesium is higher by 5.8; calcium by 15 ; sulfur by 28 and zinc by $41 \%$. The decreasing range of the content of mineral substances in the pollen of the Malus domestica. is determined: $\mathrm{K}>\mathrm{P}>\mathrm{Mg}>\mathrm{Mo} \geq$ $\mathrm{Ca}>\mathrm{S}>\mathrm{Zn}$. The coefficient of variation of elements in the ash of pollen samples from Russia ranges from $19.6 \%$ (Mo) to $29.6 \%$ (P), which indicates the relative homogeneity of the data. The average values of the coefficients of variation of pollen collected in Slovakia were found in the elements Zn (23.5\%), Ca (21\%), S (20\%) and K (15\%). Low values of the coefficients of variation are noted for the elements Mg (10\%), Mo (6.9\%) and P (4.5\%). Significant differences in the content of elements in ash are established only for $\mathrm{K}, \mathrm{Mg}$ and S.The established differences in the coefficients of variation and correlation between the elements in pollen samples from Slovakia and Russia indicate the influence of the ecological-geographical conditions for the growth of apple plants. The results confirm that pollen Malus domestica. can be used as a natural source of minerals.
\end{abstract}

Keywords: $\quad$ pollen, Malus domestica, micromorphology, ash composition, analytical scanning electron microscopy

\footnotetext{
*Corresponding author: Motyleva Svetlana, Head of the Laboratory of Physiology and Biochemistry of Federal State Budgetary Scientific Institution «All-Russian Horticultural Institute for Breeding. Agrotechnology and Nursery». Zagorevskaj Str. 4, 115598 Moscow, Russia; $\bowtie$ motyleva_svetlana@mail.ru
} 


\section{Introduction}

Plant pollen is a male gametophyte that develops in microsporangia from microspore and performs the function of pollination. Pollen is an important food for the bee colony and other insects and some animals. Pollen as part of the food chain in the animal world is a natural concentrate containing about 200 substances. Including mineral acids (triglycerides, phospholipids), flavonoids, vitamins and up to $1.6 \%$ of macro and micronutrients (Echigo et al., 1986; Villanueva et al., 2001, 2002; Somerville and Nicol, 2002; Almeida-Muradian et al., 2005; Szczesna, 2007; Yang et al., 2013), which are stimulators of biochemical and physiological processes of the body. And all this wealth is the most optimal ratio for the best assimilation. In official medicine, it is part of many pharmaceuticals. It is an effective remedy for the treatment and prevention of the absolute majority of diseases. Pollen is a natural biostimulator for the body. It has a very beneficial effect on higher nervous activity: the state of general satisfaction rises; working capacity, initiative, desire to act increases; optimism appears; decreased fatigue; speed of memorization and assimilation of new information increases. Pollen helps to produce its own body interferon, it boosts the body's immune defense; reduces the likelihood of disease, increases the elasticity of blood vessels, strengthens the capillaries, improves the adaptation of the body to weather changes, pressure drops in the atmosphere. With regular use of pollen, a qualitative improvement in the blood composition is noted, and the hematopoietic function of the body is activated. Pollen rejuvenates the entire body at the cellular level. The useful properties of pollen and the validity of its therapeutic use in various pathological conditions have been discussed in many scientific papers (Eschleman, 1996; Haro et al., 2000; Roulston and Cane, 2000; Almaraz-Abarca, 2004; Nogueira et al., 2012; Bogdanov, 2014). The chemical composition of pollen depends on the type of plant, its geographical origin, as well as other factors - climatic conditions, soil type, etc. The influence of the botanical origin of plants on the biochemical characteristics of pollen is shown (Chlebo et al., 2017). Comparative data of the mineral composition of pollen from different ecological-geographical zones little reflected in the literature.

Therefore, the purpose of this work was a comparative study of the mineral composition of the ash elements in the Malus domestica Borkh. pollen samples from different ecologicalgeographical areas.

\section{Material and methodology}

\section{Plant Material}

The objects of study were 5 samples of pollen Malus domestica from Nitra (Institute of Biodiversity Conservation and Biosafety at the Slovak University of Agriculture in Nitra) and 4 samples of pollen from the botanical garden in Moscow (Russia). The pollen was taken mechanically from the flowers in the "pink bud" state.

\section{Preparing pollen for analysis}

Preliminary dried at $T=40-50{ }^{\circ} \mathrm{C}$ pollen weighing with the mass of $10 \mathrm{~g}$ was mineralized in the muffle furnace Naberterm (Germany) at $T=400{ }^{\circ} \mathrm{C}$. The received ash was dispergated by 
ultrasound at $18 \mathrm{kHz}$ frequency for 15 minutes. The dispergate even layer was applied on the object table covered with carbonic scotch.

\section{Elemental Analysis}

The ash composition was determined by the method of enodispersive spectrometry (EDS) based on analytical scanning electron microscope - JEOL JSM 6010 LA. The microscope resolution is $4 \mathrm{~nm}$ at accelerating voltage $20 \mathrm{kV}$ (secondary electrons image), zooming is from $10 \times$ to $10000 \times$. While performing the elemental analysis the working distance (WD) is $10 \mathrm{~mm}$. Energy-dispersive spectrometer allows to carry out the quantitative $X$-ray microanalysis with the desired analyzing area. $X$-ray microanalysis data are presented in the form of standard protocols which contain the microstructure picture of the sample under study, the table of the data in weighting and atomic correlation, spectra and histograms. The spectrum example is shown in Figure 1.

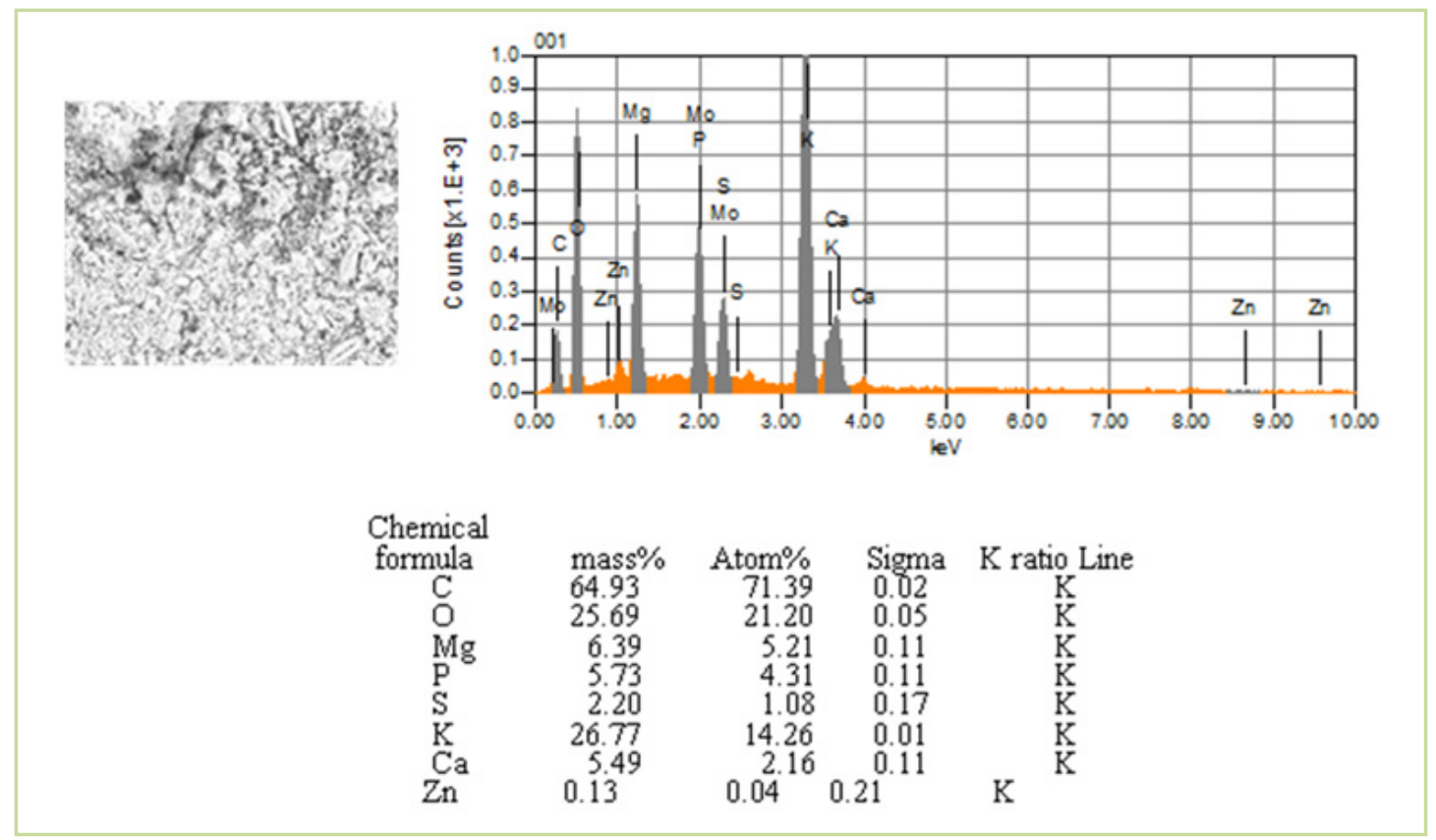

Figure 1 Report of the results of the EMF analysis: the study area, the spectrogram and the table of results

Taking into consideration the spectrum lines intensity the concentration of the desired element can be determined. The fractional accuracy of the chemical analysis is spread in the following way: at the element concentration from 1 to $5 \%$ the accuracy is less than $10 \%$; from 5 to $10 \%$ the accuracy is less than $5 \%$; at the element concentration more than $10 \%$ the accuracy is less than $2 \%$. The local analysis is $3 \mu \mathrm{m}$ the scanned area is not less than $12 \mu \mathrm{m}$. 100 ash areas of each sample were studied. 


\section{Statistical analysis}

For statistical evaluation were used standard methods using statistical software Statgraphics Centurion XVII (StatPoint Inc. USA).

\section{Results and discussion}

We analyzed potassium, phosphorus, magnesium, calcium, molybdenum, zinc and sulfur. Macro- and oligo-mineral elements from burned pollen are presented in Table 1.

Table 1 The mineral composition of pollen samples of Malus domestica Borkh,, mass.\% in the ash

\begin{tabular}{|c|c|c|c|c|c|c|c|}
\hline \multirow[t]{2}{*}{ Samples } & \multicolumn{7}{|c|}{ The studied elements } \\
\hline & $\mathbf{K}$ & $\mathbf{P}$ & Mg & Mo & $\mathbf{C a}$ & $\mathbf{S}$ & Zn \\
\hline & \multicolumn{7}{|c|}{ Pollen Malus domestica, Moscow (Russia) } \\
\hline 1 & $14.27 \mathrm{c}$ & $3.65 b$ & $4.01 \mathrm{c}$ & $3.89 b$ & $3.10 \mathrm{~b}$ & $1.41 \mathrm{~b}$ & $0.34 \mathrm{~b}$ \\
\hline 2 & $20.57 b$ & $6.34 \mathrm{a}$ & $5.39 \mathrm{~b}$ & $5.37 \mathrm{a}$ & $5.84 a$ & $1.81 \mathrm{ab}$ & $0.32 \mathrm{~b}$ \\
\hline 3 & $17.64 \mathrm{c}$ & $4.81 \mathrm{~b}$ & $4.51 \mathrm{bc}$ & $4.45 b$ & $3.71 \mathrm{~b}$ & $2.17 \mathrm{a}$ & $0.31 b$ \\
\hline 4 & $27.39 \mathrm{a}$ & $7.37 \mathrm{a}$ & $6.41 \mathrm{a}$ & $6.07 \mathrm{a}$ & $5.11 \mathrm{a}$ & $2.53 \mathrm{a}$ & $1.31 \mathrm{a}$ \\
\hline The average & $19.96 b$ & $5.54 \mathrm{ab}$ & $5.07 \mathrm{~b}$ & $4.95 b$ & $4.44 \mathrm{a}$ & $1.98 \mathrm{a}$ & $0.57 \mathrm{~b}$ \\
\hline \multirow[t]{2}{*}{ Variation coefficient $(\%)$} & $27.90 \mathrm{a}$ & $29.60 \mathrm{~b}$ & $20.80 c$ & $19.60 c$ & $28.30 \mathrm{a}$ & $24.30 \mathrm{~b}$ & $28.90 \mathrm{c}$ \\
\hline & \multicolumn{7}{|c|}{ Pollen Malus domestica, Nitra (Slovakia) } \\
\hline 1 & $29.01 \mathrm{a}$ & $6.72 \mathrm{a}$ & $3.95 b$ & $3.77 \mathrm{a}$ & $3.15 b$ & $1.33 \mathrm{a}$ & $0.28 \mathrm{~b}$ \\
\hline 2 & $21.48 \mathrm{~b}$ & $6.54 \mathrm{a}$ & $5.07 \mathrm{a}$ & $3.41 \mathrm{a}$ & $3.79 \mathrm{~b}$ & $1.31 \mathrm{a}$ & $0.49 \mathrm{a}$ \\
\hline 3 & $23.35 b$ & $6.78 \mathrm{a}$ & $4.81 \mathrm{a}$ & $3.73 a$ & $3.15 b$ & $1.52 \mathrm{a}$ & $0.38 \mathrm{a}$ \\
\hline 4 & $27.16 \mathrm{a}$ & $7.33 a$ & $4.98 \mathrm{a}$ & $4.01 \mathrm{a}$ & $5.10 \mathrm{a}$ & $1.08 \mathrm{~b}$ & $0.33 a$ \\
\hline 5 & $20.44 b$ & $6.68 \mathrm{a}$ & $5.11 \mathrm{a}$ & $4.07 \mathrm{a}$ & $3.77 \mathrm{~b}$ & $1.84 \mathrm{a}$ & $0.48 \mathrm{a}$ \\
\hline The average & $24.29 b$ & $6.81 \mathrm{a}$ & $4.78 \mathrm{a}$ & $3.79 a$ & $3.79 \mathrm{~b}$ & $1.42 \mathrm{a}$ & $0.39 a$ \\
\hline Variation coefficient (\%) & $15.10 \mathrm{a}$ & $4.50 \mathrm{~b}$ & $10.0 \mathrm{~b}$ & $6.90 \mathrm{~b}$ & $21.0 \mathrm{ab}$ & $20.0 \mathrm{a}$ & $23.50 \mathrm{a}$ \\
\hline
\end{tabular}

Note: Means in columns followed by different letters are different at $p=0.05$. Each value represents the mean of three independent experiments $( \pm \mathrm{SD})$

Potassium occurred at the highest concentrations in all tested pollen samples with average concentration in the range between $19.96-24.29 \%$ in the ash. Followed by phosphorus (5.54-6.81), magnesium (4.78-5.07), molybdenum (3.79-4.95) and calcium (3.79-4.44)\% in the ash. The oligo-elements determined presented average values ranged between $1.42-1.98 \%$ for sulfur and $0.39-0.57 \%$ for zinc. The coefficient of variation of elements in the ash of pollen samples from Moscow ranges from 19.6\% (Mo) to 29.6\% (P), which indicates the relative homogeneity of the data. The average values of the coefficients of variation of pollen collected in Nitra were found in the elements Zn (23.5\%), Ca (21\%), S (20\%) and K (15\%). Low values of the coefficients of variation are noted for the elements Mg (10\%), Mo (6.9\%) and P (4.5\%). Significant differences in the content of elements in ash are established only for $\mathrm{K}, \mathrm{Mg}$ and $\mathrm{S}$. 
Calculated correlation coefficients between elements (Table 2). In pollen samples from Russia it is established that, there is a high correlation not only between macro-elements, for example, $\mathrm{K}$ and $\mathrm{Mg}(r=0.99) ; \mathrm{K}$ and $\mathrm{P}$ and $\mathrm{K}$ and $\mathrm{Mo}(r=0.97) ; \mathrm{P}$ and $\mathrm{Mg}$ and $\mathrm{P}$ and $\mathrm{Mo}(r=0.99) ; \mathrm{Mg}$ and Mo ( $r=0.851)$ but also between oligo-mineral elements $\mathrm{S}$ and $\mathrm{Zn}(r=0.75)$. Weak correlation found between $\mathrm{Ca}$ and $\mathrm{S}(r=0.42)$ and $\mathrm{Ca}$ and $\mathrm{Zn}(r=0.35)$. The mean correlation is between $\mathrm{P}$ and S ( $r=0.76) ; \mathrm{P}$ and $\mathrm{Zn}(r=0.73) ; \mathrm{Mg}$ and $\mathrm{Ca}(r=0.79) ; \mathrm{Mg}$ and S ( $r=0.78)$; Mo and $\mathrm{Zn}$ $(r=0.77)$; S and Zn (0.75).

Table 2 Correlation matrix for the 6 elements in the ash pollen of Malus domestica Borkh in Moscow (Russia)

\begin{tabular}{lcccccc}
\hline Elements & $\mathbf{P}$ & Mg & Mo & Ca & S & Zn \\
\hline K & $0.97^{*}$ & 0.99 & $0.97^{*}$ & $0.72^{*}$ & 0.84 & 0.87 \\
P & & $0.98^{*}$ & $0.99^{*}$ & $0.87^{*}$ & $0.76^{*}$ & 0.73 \\
Mg & & 0.99 & 0.79 & 0.78 & $0.83^{*}$ \\
Mo & & & 0.86 & $0.76^{*}$ & $0.76^{*}$ \\
Ca & & & & $0.41^{*}$ & $0.34^{*}$ \\
S & & & & & 0.74 \\
\hline
\end{tabular}

Note: *Significant according to the t-test $(p<0.05)$

Table 3 presents the correlation matrix between the elements in the pollen ash from Slovakia. High correlation is established by the elements $\mathrm{P}$ and $\mathrm{Ca}(r=0.79), \mathrm{Mg}$ and $\mathrm{Zn}(r=0.78)$, $\mathrm{P}$ and $\mathrm{Mg}(r=0.58)$, and $\mathrm{P}$ and $\mathrm{K}(r=0.51)$. High negative correlations were found for the elements K and Zn ( $r=-0.91), \mathrm{K}$ and $\mathrm{Mg}(r=-0.77), \mathrm{K}$ and S ( $r=-0.67)$, and $\mathrm{P}$ and $\mathrm{S}(r=-0.57)$. Low correlations were found between P and $\mathrm{Mg}(r=0.11), \mathrm{Mg}$ and Mo $(r=0.10)$, Ca and Zn $(r=-0.01)$.

Table 3 Correlation matrix for the 6 elements in the ash pollen of Malus domestica Borkh in Nitra (Slovakia)

\begin{tabular}{lcccccc}
\hline Elements & $\mathbf{P}$ & $\mathbf{M g}$ & Mo & $\mathbf{C a}$ & $\mathbf{S}$ & $\mathbf{Z n}$ \\
\hline $\mathbf{K}$ & $0.53^{*}$ & $-0.77^{*}$ & 0.15 & $0.12^{*}$ & -0.67 & -0.97 \\
$\mathbf{P}$ & & 0.11 & $0.58^{*}$ & 0.79 & $-0.57^{*}$ & -0.53 \\
$\mathbf{M g}$ & & $0.10^{*}$ & $0.50^{*}$ & 0.21 & $0.78^{*}$ \\
Mo & & & $0.40^{*}$ & $0.27^{*}$ & $-0.24^{*}$ \\
$\mathbf{C a}$ & & & & -0.51 & -0.01 \\
$\mathbf{S}$ & & & & & $0.51^{*}$ \\
\hline
\end{tabular}

Note: *Significant according to the $t$-test $(p<0.05)$

The correlation between elements in pollen samples from Nitra is very different from the correlation established between elements in pollen samples from Moscow. The established 
differences in the coefficients of variation and correlation between the elements in pollen samples from Slovakia and Russia indicate the influence of the ecological-geographical conditions for the growth of apple plants.

The influence of ecological and geographical conditions on the mineral composition of pollen Malus domestica has been established. In pollen samples from Slovakia, the proportion of potassium and phosphorus is higher by $18 \%$. In pollen samples from Moscow, the proportion of magnesium is higher by 5,8 ; calcium by 1,5 ; sulfur by 28 and zinc by $41 \%$ respectively. Differences in the content of elements in pollen ashes may be related to the type of soil and the various ecological and geographical conditions of Malus domestica growing, this is confirmed by the study of honey (Felsner et al., 2004). Our results on the content of potassium, calcium in pollen are similar to the data reported in studies of the pollen of other plant species sunflower, eucalyptus (Somerville and Nicol, 2002; Villanueva et al., 2001; Szczesna, 2007).

Modern nutritional research confirmed that minerals and trace elements are the vital importance to the life activities of the human body. For instance, potassium has function in the maintenance of water balance and distribution kidney and adrenal function, calcium plays an important role in building and maintaining the bones and teeth blood clotting, transmitting of the nerve impulses. Magnesium regulates nerve simulation and muscle contraction. The participation of zinc and sulfur in many kinds of enzymatic composition might play an important role in promoting the metabolism of organisms to strengthen immune ability (Avcin et al., 1991).

\section{Conclusions}

There is very little published data on the mineral composition of pollen from Rosaceae. This makes comparison with literature data difficult. Our studies have found that in the ash residue of pollen Malus domestica, regardless of ecological and geographical conditions, dominated by $\mathrm{K}$ and $\mathrm{P}$, then $\mathrm{Mg}$, Mo and $\mathrm{Ca}, \mathrm{S}$ and $\mathrm{Zn}$ in smaller quantities, this indicates that the order of accumulation of elements in the pollen Malus domestica is determined genetically. The influence of ecological and geographical conditions on the content of potassium and calcium in the ash residue of pollen Malus domestica has been established. These results contribute to the mineral content information of pollens Malus domestica in Russia and Slovakia, and show that pollen can be considered good source of minerals.

\section{Acknowledgements}

This study was supported by the International Visegrad Fund through the project V4EaP, № 51700373.

\section{References}

AVCIN, A.P., CHAVORONKOV, A.A., RISCH, M.A., STROCHKOVA, Л.C. 1991. Micro-elementozi икроэлементозы chelovekaa. M: Medicina. 496 p.

ALMARAZ-ABARCA, N., CAMPOS, M.G., ÁVILA-REYES, A. J., NARANJO-JIMÉNEZ, N., HERRERA-CORRAL, I., GONZÁLEZ-VALDEZ, L.S. 2004. Variability of antioxidant activity among honeybee-collected pollen of different botanical origin. In Interciencia, vol. 29(10). p. 574-578. 
ALMEIDA-MURADIAN, L.B., PAMPLONA, L., C., COIMBRA, S., BARTH, M.O. 2005. Chemical composition and botanical evaluation of dried bee pollen pellets. In Journal of Food Composition and Analysis, vol. 18. p. 105-111. https://doi.org/101016/jjfca200310008

BOGDANOV, S. 2014. Pollen: Production Nutrition and Health: A Review. In Bee Product Science [cit. 2018-11-16]. Available at: http://wwwbee-hexagonnet/

ECHIGO, T., TAKENAKA, T., YATSUNAMI, K. 1986. Comparative studies on chemical composition of honey royal jelly and pollen loads. In Bull Fac Agr Tamagawa, vol. 26. p. 1-12.

CHLEBO, R., ADAMCHUK, L. 2017. Pollen natural resources for bees in Slovakia. In Agrobiodiversity for Improving Nutrition. Health and Life Quality, vol. 1, p. 70-75. http://dx.doi.org/10.15414/ agrobiodiversity.2017.2585-8246.70-75

ESCHLEMAN, M.M. 1996. In Introductory Nutrition and diet therapy. J.B. Lippincott Company : Philadelphia. 324 p. ISBN 978-0397547869.

HARO, A., LOPEZ-ALIAGA, I., LISBONA, F., BARRIONUEVO, M., ALFEREZ, M. J., CAMPOS, M. S. 2000. Beneficial effect of pollen and/or propolis on the metabolism of iron, calcium, phosphorus and magnesium in rats with nutritional ferropenic anemia, In Journal of Agricultural and Food Chemistry, vol. 48, p. 5715-5722. https://doi.org/101021/jf000635h

NOGUEIRA, C., IGLESIAS, A., FEAS, X., ESTEVINHO, L. M. 2012. Commercial bee pollen with different geographical origins: a comprehensive approach. In International Journal of Molecular Sciences, vol.13, p. 11173-11187. https://doi.org/103390/ijms130911173

YANG, K., WU, D., YE, X., LIU, D., CHEN, J., SUN, P. 2013 Characterization of chemical composition of bee pollen in China. In Journal of Agricultural and Food Chemistry, vol. 61. p. 708-718. https://doi. org/101021/jf304056b

ROULSTON, T.H., CANE, J.H. 2000. Pollen nutritional content and digestibility for animals. In Plant Syst. Evol., vol. 222(1-4), p. 187-209. https://doi.org/10.1007/BF00984102

SOMERVILLE, D.C., NICOL, H.I. 2002. Mineral content of honeybee-collected pollen from southern New South Wales. In Australian journal of experimental agriculture, vol. 42(8), p. 1131-1136 https:// doi.org/10.1071/EA01086

SZCZESNA, T. 2007. Concentration of selected elements in honeybee-collected pollen. In Journal of Apicultural Science, vol. 51(1), p. 5-13.

VILLANUEVA, M.T.O., MARQuinA, A.D., SERRANO, R.B., ABELlÁN, G.B. 2001. Mineral content of commercial pollen. In International Journal of Food Sciences and Nutrition, vol. 52(3), p. 243-249. https://doi.org/10.1080/09637480020027000-3-1

VILLANUEVA, M. T. O., MARQUINA, A. D., SERRANO, R. B., ABELLAN, G. B. 2002. The importance of bee collected pollen in the diet: study of its composition. In International Journal of Food Science and Nutrition, vol. 53, p. 217-224. https://doi.org/101080/09637480220132832 